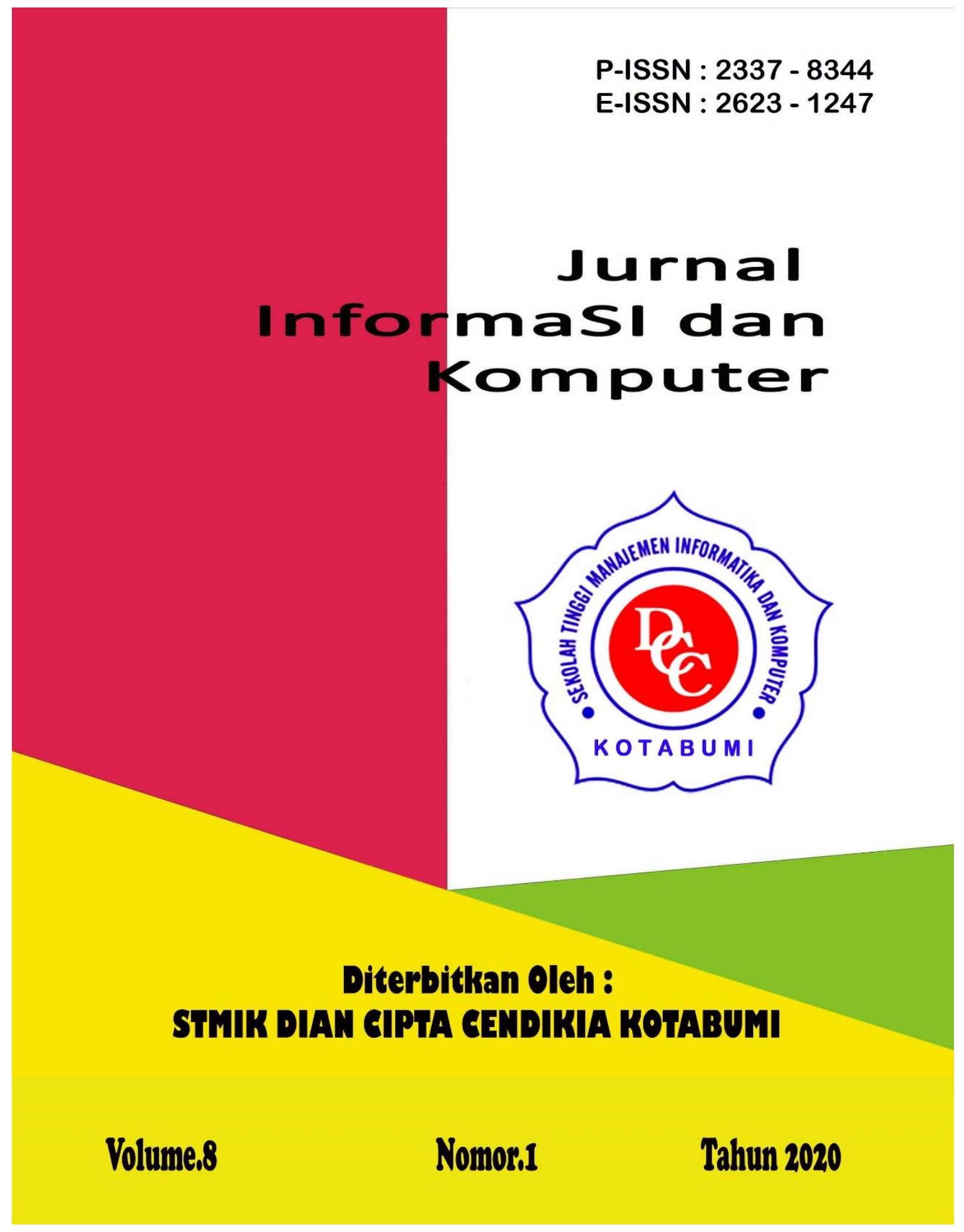




\section{Penerbit:}

STMIK DIAN CIPTA CENDIKIA KOTABUMI

Bekerjasama dengan LPPM STMIK DCC Kotabumi

Hak atas naskah/tulisan tetap berada pada penulis, isi diluar tanggung jawab

Penerbit dan Dewan Penyunting

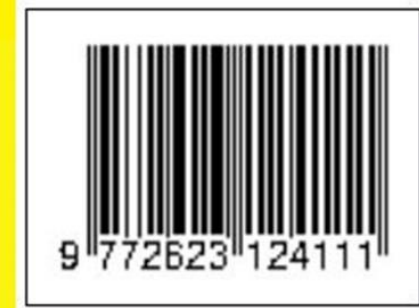




\section{PENGANTAR REDAKSI}

Puji syukur dipanjatkan kehadirat Tuhan Yang Maha Esa, atas karunia dan limpahan rahmatNYA jualah Jurnal Informatika dan komputer (InfoKom) STMIK Dian Cipta Cendikia Kotabumi ini dapat terwujud.Jurnal Informatika dan Komputer (InfoKom) yang terbit dua (2) kali dalam setahun ini merupakan suatu wadah untuk penyebar luasan hasil-hasil penelitian, studi pustaka, karya ilmiah yangberkaitan dengan Informatika dan Komputer khususnya bagi dosen-dosen STMIK Dian Cipta Cendikia Kotabumi serta umumnya para cendikiawan, praktisi, peneliti ilmu Informatika dan Komputer.

Harapan, dengan diterbitkannya Jurnal Informatika dan Komputer (InfoKom) ini sebagai salah satu bentuk sumbangan pemikiran dalam pengembangan ilmu informatika dan komputer yang berkaitan dengan kajian-kajian di bidang tekhnologi Informatik, Komunikasi Data dan Jaringan Komputer, perancangan dan Rekayasa Perangkat Lunak, serta ilmu-ilmu yang terkait dengan bidang Informatika dan Komputer lainnya.

Berkenaan dengan harapan tersebut, kepada para peneliti, dosen dan praktisi yang memiliki hasil-hasil penelitian, kajian pustaka, karya ilmiah dalam bidang tersebut diatas, dengan bangga redaksi Jurnal Informatika dan Komputer (JIK) menerima naskah ringkasan untuk dimuat pada jurnal Informatika dan Komputer (InfoKom) STMIK Dian Cipta Cendikia Kotabumi dengan berpedoman pada penulisan naskah jurnal sebagaimana dilampirkan pada halaman belakang (Bagian kulit dalam) buku jurnal ini.

Mutu dari suatu jurnal ilmiah tidak hanya ditentukan oleh para pengelolanya saja, tetapi para penulis dan pembaca jualah yang mempunyai peranan besar dalam meningkatkan mutu jurnal Informatika dan Komputer ini. Merujuk pada realita ini kamu sangat mengharapkan peran aktif dari peneliti untuk bersama-sama menjaga dan memelihara keberlangsungan dari jurnal Informatika dan Komputer STMIK Dian Cipta Cendikia Kotabumi ini. Yang juga tidak kalah pentingnya dari partisipasi tersebut diatas, adalah saran dan kritik yang membangun dari pembaca yang budiman agar kiranya dapat disampaikan langsung kepada redaksi JIK. Saran dan kritik yang membangun akan dijadikan masukan dan pertimbangan yang sangat berarti guna peningkatan mutu dan kualitas Jurnal Informatika dan Komputer STMIK Dian Cipta Cendikia Kotabumi.

Tak lupa diucapkan terima kasih yang tak terhingga atas perhatian dan kerjasama dari semua pihak yang tak dapat disebutkan satu persatu hingga dapat diterbitkan nya Jurnal Informatika dan Komputer (InfoKom) STMIK Dian Cipta Cendikia Kotabumi. Semoga apa yang telah diperbuat untuk kebaikan akan menjadi amal ibadah, amin.

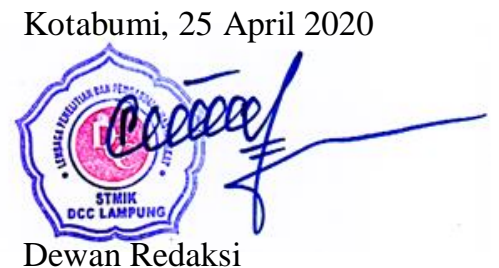




\section{JURNAL INFORMASI DAN KOMPUTER}

Volume 8 Nomor 1 April 2020

Jurnal Informasi dan Komputer merupakan Sarana informasi ilmu pengetahuan, Tekhnologi dan Komunikasi yang berupa hasil penelitian, tulisan ilmiah, Ataupun studi pustaka. Jurnal ini terbit dua kali setahun pada bulan April dan Oktober. Berisi hasil penelitian ilmiah di bidang informatika yang bertujuan untuk menghubungkan adanya kesenjangan antar kemajuan teknologi dan hasil penelitian. Jurnal ini di terbitkan pertama kali pada tahun 2013.

Penanggung Jawab:

Ketua STMIK Dian Cipta Cendikia

Kotabumi

\section{Pembina:}

Ketua STMIK Dian Cipta Cendikia

Kotabumi

Ketua Lembaga Penelitian STMIK Dian

Cipta Cendikia Kotabumi

\section{Pimpinan Redaksi}

Dwi Marisa Efendi,.S.Kom.,M.Ti

\section{Redaksi pelaksana}

Rustam,.S.Kom,.M.Ti (STMIK Dian

Cipta Cendikia Kotabumi)

Nurmayanti M.Kom (STMIK Dian

Cipta Cendikia Kotabumi)

Sukatmi,.S.Kom., M.Kom (AMIK DCC

Bandar Lampung)

Sampurna Dadi Riskiono,M.Kom

(Universitas Teknokrat Indonesia)

Ifo Wahyu

Pratama,S.Kom.,M.Ti(AMIK MASTER

Lampung)

\section{Mitra Bestari}

Merri Parida.,M.Kom (STMIK Dian

Cipta Cendikia Kotabumi)

Amarudin,S.Kom.,M.Eng (Universitas

Teknokrat Indonesia)

Didi Susianto.,S.T.,M.Kom (AMIK

DCC Bandar Lampung)

Alhibarsyah.,S.T.,M.Kom (Stmik Tunas

Bangsa Bandar Lampung)

Kemal Farouq Mauladi

.,S.Kom.,M.Kom (Universitas Islam

Lamongan)

Agus Setiawan S.Pd.,M.Eng

(Universitas Muhammadiyah

Lamongan)

Penerbit : STMIK Dian Cipta Cendikia Kotabumi Bekerja Sama Dengan LPPM STMIK Dian Cipta Cendikia Kotabumi.

\section{Alamat Redaksi/Penerbit:}

Jl. Negara No. 3 Candimas Kotabumi

Lampung Utara

No Telpon/Fax 072423003

Email : 1ppm-stmik@dcc.ac.id 


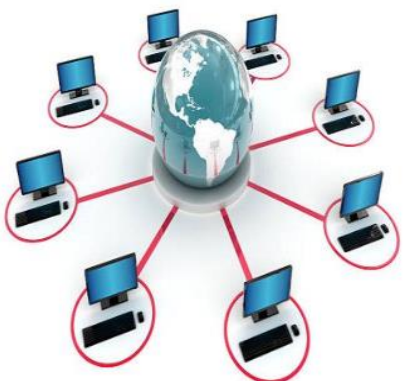 \\ JURNAL INFORMASI DAN KOMPUTER VOL. 8 NO. 1 THN. 2020}

\section{DAFTAR ISI}

\section{Halaman}

Sistem Pendukung Keputusan Penentuan Lahan Kopi Terbaik Dengan Metode

Ahp (Analytic Hierarchy Process)

Sidik Rahmatullah, Rendy Abdurahman (AMIKKOM Jogja,

STMIK Dian Cipta Cendikia Kotabumi)

Rancang Bangun Sistem Informasi Pada Program Pembangunan Pemberdayaan

Masyarakat Desa( P3md ) Berbasis Web Mobile

Ferly Ardhy, Firmansyah, Sidik Rahmatullah,(IIB Darma Jaya Bandar Lampung

STMIK Dian Cipta Cendikia Kotabumi, AMIKKOM Jogja)

Sistem Informasi Pengolahan Data Alumni Sekolah Menengah Atas (Sma)

Merri Parida, Nindiya Ova Rahmawati (AMIKKOM Jogja,

STMIK Dian Cipta Cendikia Kotabumi)

SISTEM INFORMASI GEOGRAFIS PUSKESMAS BESERTA SARANA

DAN PRASARANA BERBASIS WEB MOBILE

Nurmayanti, Windy Dwi Bahari (AMIKOM Jogja,

STMIK Dian Cipta Cendikia Kotabumi)

Rancang Bangun Sistem Informasi Konseling Untuk Sekolah Menengah Kejuruan

(Smk) Berbasis Website

Aliy Hafiz1, Galih Rakasiwi, Ifo Wahyu Pratama, Agus Komarudin,

Bambang Suparapto, Fathurrahman Kurniawan Ikhsan

(AMIK Dian Cipta Cendikia Bandar Lampung,

Universitas Nahdhatul Ulama Lampung, AMIK Dian Cipta Cendikia Pringsewu,

Universitas Mitra Indonesia, Lampung) .....

Sistem Pendukung Keputusan Pemilihan Driver Terbaik Menggunakan Metode

Weight Product (Wp)

Dina Lorenza, Pitrawati (STMIK Dian Cipta Cendikia Kotabumi

AMIK Dian Cipta Cendikia)

Rancang Bangun Sistem Informasi Pembayaran Mahasiswa

Darsin(Universitas Megou pak Tulang Bawang)

Sistem Informasi Geografis Bengkel Motor Honda Resmi Bandar Lampung

Sukatmi, Nuraini (AMIK Dian Cipta Cendikia Bandar Lampung).....

Sistem Pakar Diagnosa Penyakit Kulit Wajah Dengan Metode

Certainty Factor Pada Klinik Skin Rachel

Dwi Marisa Efendi, Putri Yulita Sari (IIB Darmajaya Bandar Lampung,

STMIK Dian Cipta Cendikia Kotabumi)..... 
Sistem Informasi Monitoring Siswa Pada Mts Al-Islamiah Bunut Kabupaten Pesawaran Yuli Syafitri ${ }^{2}$, Reni Astika ${ }^{1}$, Septian Hernando $^{3}$ AMIK Dian Cipta Cendikia

Aplikasi Kamus Bahasa Jepang Berbasis Mobile Android

Rustam $^{2}$, A Yanda Febry Pangestu ${ }^{2}$ Sistem Informasi, Teknologi Komputer ${ }^{1}$, IIB Darmajaya

Bandar Lampung ${ }^{2}$ STMIK Dian Cipta Cendikia Kotabumi 


\title{
SISTEM PAKAR DIAGNOSA PENYAKIT KULIT WAJAH DENGAN METODE CERTAINTY FACTOR PADA KLINIK SKIN RACHEL
}

\author{
Dwi Marisa Efendi ${ }^{1}$ Putri Yulita Sari ${ }^{2}$ \\ Teknologi Komputer ${ }^{1}$, Sistem Informasi ${ }^{2}$ \\ IIB Darmajaya ${ }^{1}$ STMIK Dian Cipta Cendikia Kotabumi ${ }^{2}$ \\ J1.Negara Nomor 03 Candimas Kotabumi Lampung Utara \\ E-mail: $\underline{\text { dwimarisa89@gmail.com }}^{1}$ putriyulitasari@gmail.com ${ }^{1}$
}

\begin{abstract}
ABSTRAK
Kulit wajah merupakan jendela yang bisa membantu alam mendeteksi kelainan atau penyakit lain di dalam tubuh. Dengan adanya pengaruh tersebut kita mudah sekali terkena beberapa penyakit atau gangguan pada kulit wajah karena kulit wajah merupakan bagian yang paling sensitif dibandingkan kulit bagian lain. Tujuan dari penelitian ini adalah untuk merancang dan mengimplementasikam sistem pakar yang dapat memberikan informasi atau doagnosis awal jenis penyakit kulit wajah. Metode yang digunakan dalam membuat sistem pakar ini adalah metode certainty factor serta menggunakan metode extreme programming (XP). Hasil akhir dari pembuatan sistem pakar ini adalah membantu masyarakat dalam mendiagnosa awal jenis penyakit kulit wajah yang di alami sehingga dalam pengobatannya dapat mudah diketahui.
\end{abstract}

Kata Kunci : Sistem Pakar, Metode Certainty Factor, Penyakit Kulit Wajah, Extreme Programming, Hypertext Preprocessor, MySQL, Unifed Modeling Language

\section{ABSTRACTS}

Facial skin is a window that can help nature detect abnormalities or other diseases in the body. With this effect, we are easily exposed to several diseases or disorders of the facial skin because facial skin is the most sensitive part compared to other parts of the skin. The purpose of this research is to design and implement an expert system that can provide information or initial diagnosis of types of facial skin diseases. The method used in making this expert system is the certainty factor method and using the extreme programming (XP) method. The end result of making this expert system is to help people diagnose early types of facial skin diseases that are experienced so that the treatment can be easily identified.

Keywords: Expert System, Certainty Factor Method, Facial Skin Disease, Extreme Programming, Hypertext Preprocessor, MySQL, Unifed Modeling Language

\section{PENDAHULUAN}

Kulit merupakan organ terbesar dalam tubuh, luasnya sekitar $2 \mathrm{~m}^{2}$. Kulit merupakan bagian terluar dari Kulit merupakan organ terbesar dalam tubuh, luasnya sekitar $2 \mathrm{~m}^{2}$. Kulit merupakan bagian terluar dari tubuh manusia yang lentur dan lembut. Dan merupakan benteng pertahanan pertama dari berbagai ancaman yang datang dari luar seperti kuman, virus dan bakteri. Bagi sebagian orang merawat kulit tidak terlalu penting. Padahal dengan kulit yang sehat penyakit-penyakit akan sulit menyerang tubuh kita. Penulis membahas mengenai kulit wajah karena peta wajah merupakan jendela yang bisa membantu alam mendeteksi kelainan atau penyakit lain di dalam tubuh. Segala permasalahan yang muncul di kulit wajah bisa mencerminkan kondisi kesehatan lainnya.

Oleh karena itu, ada baiknya mengenali gejala penyakit melalui tanda yang diisyaratkan oleh wajah. Hal pertama yang dilakukan orang awam apabila terjadi gangguan pada kulit wajah adalah konsultasi kepada dokter. Orang awam lebih mempercayakan kepada pakar atau dokter ahli yang sudah mengetahui lebih banyak 
tentang kesehatan. Permasalahan yang sering muncul adalah ketersediaan doket ahli atau pakar yang memiliki pengetahuan dibidang tertentu cukup terbatas sementara banyak pasien yang harus segera diketahui penyakitnya dan segera ditangani. Disamping itu, adanya pakar atau dokter yang jam kerja prakteknya terbatas, sehingga kebanyakan pasien yang harus menunggu antrian dan jarak/lokasi dari pakar dengan pasien dan biaya konsultasi yang cukup mahal.

maka yang akan menjadi pembahasan dalam identifikasi masalah adalah :

1. Kurang nya pemahaman masyarakat awam terhadap penyakit kulit sehingga memperlambat masa penyembuhan.

2. Dibutuhkannya sebuah sistem untuk membantu dan menjadi alternative diagnosa penyakit kulit.

Adapun tujuan dan manfaat dari penelitian ini adalah sebagai berikut :

1. Mengimplementasikan sebuah aplikasi agar dapat menjadi alternative untuk mengantisipasi pengobatan secara cepat dan tepat berdasarkan gejala yang diinputkan.

2. Merancang sebuah sistem pakar untuk mendiagnosa penyakit kulit wajah berdasarkan gejala yang diinputkan dan dapat menerapkan metode certainty factor untuk mendiagnosa penyakit kulit wajah.

3. Membuat sistem pakar penyakit kulit wajah yang dapat membantu menghasilkan sistem yang baik.

\section{METODE PENELITIAN}

Dalam Penelitian ini peneliti menggunakan metode pengumpulan data seperti observasi, wawancara dan studi pustaka. Selain itu juga peneliti menggunakan metode Certainty Factor sebagai penunjang kepakaran dan metode Extreme Programming (XP) sebagai metode pengembangan sistem

\subsection{Sistem Pakar}

Sistem Pakar adalah sistem komputer yang ditujukan untuk meniru semua aspek (emulates) kemampuan pengambilan keputusan (decision making) seorang pakar. Sistem pakar memanfaatkan secara maksimal pengetahuan khusus selayaknya seorang pakar untuk memecahkan masalah (Rika Rosnelly;2012: 2).
Keuntungan Sistem Pakar:

1. Memungkinkan orang awam bisa mengerjakan pekerjaan para ahli.

2. Bisa melakukan proses secara berulang secara otomatis.

3. Menyimpan pengetahuan dan keahlian para pakar.

4. Mampu mengambil dan melestarikan keahlian para pakar (terutama yang termasuk keahlian langka).

5. Memiliki kemampuan untuk mengakses pengetahuan.

6. Menghemat waktu dalam pengambilan keputusan

7. Dapat memecahkan masalah lebih cepat dari pada kemampuan manusia dengan catatan data yang sama.

Kelemahan Sistem Pakar :

1. Biaya yang diperlukan untuk membuat, memelihara, dan mengembangkannya sangat mahal.

2. Sulit dikembangkan, hal ini erat kaitannya dengan ketersediaan pakar dibidangnya dan kepakaran sangat sulit diekstrak dari manusia

\subsection{Certainty Factor}

Pengertian Certainty Factor Teori Certainty Factor(CF) diusulkan oleh Shortliffe dan Buchanan pada tahun 1975 untuk mengakomadasi ketidak pastian pemikiran(inexact reasoning)seorang pakar[4]. Seorang pakar, (misalnya dokter) sering kali tidak pasti dalam menganalisa suatu informasi yang ada dengan cara mengungkapkan "mungkin", "kemungkinan besar", "hampir pasti”.

Rumus dasar $\mathrm{CF}$ :

$C F(h, e)=M B(h, e)-M D(h, e)(1)$

Keterangan:

$\mathrm{CF}(\mathrm{h}, \mathrm{e})=$ Certainty Factor (faktor kepastian) dalam hipotesish dipengaruhi oleh evidence (gejala) e.

$\mathrm{MB}(\mathrm{h}, \mathrm{e})=$ Measure of Belief (tingkat keyakinan), merupakan ukuran kepercayaan dari hipotesis $\mathrm{h}$ dipengaruhi oleh evidence (gejala) e.

$\mathrm{MD}(\mathrm{h}, \mathrm{e})=$ Measure of Disbelief (tingkat ketidakyakinan), merupakan ukuran ketidakpercayaan dari hipotesis $\mathrm{h}$ dipengaruhi oleh gejala e. 
$\mathrm{h}=$ Hipotesa atau konklusi yang dihasilkan (antara 0 dan 1).

$\mathrm{e}=$ Evidence atau peristiwa atau fakta (gejala)

Berikut ini deskripsi beberapa kombinasi certainty factor terhadap berbagai kondisi :

Certainty Factor memiliki sebuah aturan JIKA

E MAKA $\mathrm{H}$ adalah sebagai berikut:

$\mathrm{CF}(\mathrm{H}, \mathrm{e})=\mathrm{CF}(\mathrm{E}, \mathrm{e}) * \mathrm{CF}(\mathrm{H}, \mathrm{E})$

CfcombineCF[H,E $] 1,2=\mathrm{CF}[\mathrm{H}, \mathrm{E}] 1+\mathrm{CF}[\mathrm{H}, \mathrm{E}] 2$

* [1-CF[H,E]1]....

CFcombineCF $[\mathrm{H}, \mathrm{E}] \mathrm{old} 3=\mathrm{CF}[\mathrm{H}, \mathrm{E}] \mathrm{old}+\mathrm{CF}[\mathrm{H}, \mathrm{E}]$

$3 *[1-\mathrm{CF}[\mathrm{H}, \mathrm{E}] \mathrm{old}]$

\subsection{Extreme Programming (XP)}

Metode Extreme Programing Menurut Prabowo dalam (Supriyatna, 2018) Extreme Programming (XP) merupakan sebuah proses rekayasa perangkat lunak yang cenderung menggunakan pendekatan berorientasi objek dan sasaran dari metode ini adalah tim yang dibentuk dalam skala kecil sampai medium serta metode ini juga sesuai jika tim dihadapkan dengan requirementy ang tidak jelas maupun terjadi perubahan-perubahan requirement yang sangat cepat.

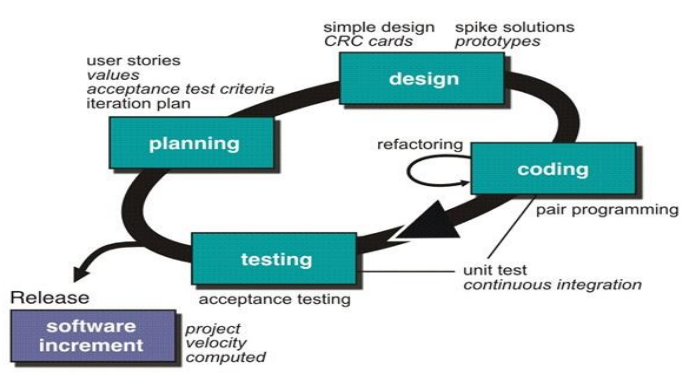

Gambar 1 Extreme Programming (XP)

Ada empat nilai utama yang sangat mendasar dalam metodologi XP yaitu:

\section{Komunikasi (Communication)}

Komunikasi menjadi hal yang penting untuk mencapai kebenaran dalam sebuah ilmu komputer. Minimnya komunikasi akan menimbulkan permasalahan dalam proses pembangunan atau pengembangan sebuah software. Pada metodologi XP, komunikasi ini sangant diutamakan dalam setiap fasenya, seperti pada perencanaan komunikasi sangat dijaga dengan penggunaan ahli (expert customer) dari perangkat lunak yang sedang dikembangkan guna menentukan hal yang tepat menjadi kebutuhan dari customer. Komunikasi ini pun tetap oleh pengembang (developer) dengan pihak klien (customer) pada saat coding sampai dengan penyelesaian akhir program, sehingga saat ada kekeliruan dapat segera diperbaiki.

\section{Kesederhanaan (Simplicity)}

XP mencoba untuk mencari solusi paling sederhana dan praktis. Perbedaan metode ini dengan metodologi pengembangan sistem konvensional lainnya terletak pada proses desain dan coding yang terfokus pada kebutuhan saat ini dari pada kebutuhan besok, seminggu lagi atau sebulan lagi. Lebih baik melakukan hal yang sederhana dan mengembangkannya besok jika diperlukan.

\section{Masukan dan Umpan Balik (Feedback)}

Metodologi XP memungkinkan project mendapatkan masukan atau koreksi lebih awal dan sesering mungkin, baik dari customer, dari team, dari end use sesungguhnya, atau dari steakeholder lain yang berwenang dalam project dan dari yang lain. Hal ini sangat membantu dalam mengidentifikasi masalah lebih awal sehingga dapat segera diselesaikan. Ini hanya dapat terjadi dengan komunikasi yang optimal selama proses pengembangan berjalan.

\section{Keberanian (Courage)}

Berani mencoba ide baru. Berani mengerjakan kembali dan setiap kali kesalahan ditemukan langsung diperbaiki. Contoh dari courageadalah komitmen untuk selalu melakukan design dan coding untuk saat ini dan bukan untuk saat esok. Ketika ada kode yang terlalu rumit, sulit dibaca dan dipahami, tidak sesuai dengan kemauan pelanggan, dan lain-lain maka seharusnya kode program seperti itu di refactor (kalau perlu dibangun ulang). Hal ini menjadikan pengembangan merasa nyaman dengan refactoring program ketika diperlukan.

Ada empat tahap pengembangan sistem dalam metode XP, yaitu:

\section{Planning}

Bagian ini melakukan pengumpulan informasi kemudian menyeleksinya (yang dibantu oleh 
user ahli atau pakar) sehingga sesuai dengan kebutuhan aplikasi.

\section{Design}

Aktifitas ini memiliki prinsip dasar sederhana, identifikasi dan pengaturan kelas-kelas dalam konsep object oriented. Jika dalam prosesnya menemui kesulitan maka dilakukan langkah spike solusion yaitu pembuatan prototype.

\section{Coding}

Aktifitas utama adalah refactoring yaitu pengembangan design menuju implementasi pair program yang menjadi bagian dari fase ini, dilakukan untuk real time programsolving dan real timequality assurance. Sebelum coding dilakukan siapkan unit test yang akan digunakan pada fase selanjutnya (test).

\section{Test}

Fase ini merupakan fase pengujian hasil dari aplikasi yang telah dibangun. Pengujian yang dilakukan mengacu unit test yang telah disusun mulai dari awal fase coding.

\section{Release}

Fase ini merupakan tahap dimana sudah tidak ada lagi stories (data) dari user yang diimplementasikan sehingga semua kebutuhan sistem dianggap telah terpenuhi. Tidak ada lagi perubahan arsitektur, design atau pelaksanaan coding

\subsection{Penyakit Kulit}

Penyakit kulit merupakan kelainan kulit yang diakibatkan oleh adanya jamur, kuman-kuman, parasit, virus maupun infeksi. Penyakit jamur dapat hidup dan berkembang biak ditempat pembuangan sampah dan pada petugas pengangkut sampah. Penyakit kulit dapat menyerang keseluruh atau sebagian tubuh tertentu. Bahan-bahan yang mengandung nitrit yang terdapat dalam sampah secara kontak langsung dapat menimbulkan alergi dan iritasi. Penyakit kulit dapat menyerang siapa saja terutama mereka yang berhubungan dengan sampah. Kejadian penyakit kulit pada pekerja pengangkut sampah merupakan suatu hal yang harus dihindari atau dicegah oleh pengangkut sampah agar tidak mengganggu aktifitas dan produktifitas kerja. Kulit wajah adalah lapisan terluar dari wajah/muka (bagian depan kepala) pada manusia yang meliputi wilayah dari dahi hingga dagu.(Kaltim Pos, 2016).

\subsection{Jenis-Jenis Kulit Wajah}

\section{a. Kulit berminyak}

Jenis kulit wajah ini merupakan jenis kulit wajah yang paling susah sekali untuk merawatnya karena jenis kulit wajah ini cenderung memiliki minyak yang tidak terkontrol, artinya produksi minyak pada jenis kulit berminyak ini diatas rata-rata dibandingkan jenis kulit normal

\section{b. Kulit sensitif}

Jenis kulit wajah ini merupakan jenis wajah yang sangat peka sekali terhadap rangsangan, baik rangsangan dari lingkungan luar maupun dari benda-benda yang menempel pada kulit wajah.

\section{c. Kulit kering}

Jenis kulit wajah kering ini kebalikan dari jenis kulit wajah berminyak, jenis kulit wajah kering akan sangat sulit sekali keluar minyak pada kulit karena kelenjar minyak pada kulit wajah cenderung tidak mampu memproduksi minyak dengan baik.Kulit normalBeruntung sekali bagi anda yang memiliki jenis kulit normal ini karena jenis kulit wajah ini cenderung seimbang, tidak terlalu kering dan tidak terlalu berminyak.

\section{d. Kulit kombinasi}

Ini merupakan jenis kulit yang unik sekali, kadang disuatu saat kulit ini akan mudah berminyak, kadang kering dan kadang normal.Jenis-Jenis Penyakit Pada Kulit WajahAdabanyak jenis penyakit kulit yang berfokus di area wajah dan sekitarnya, diantaranya adalah sebagai berikut :

\section{e. Jerawat}

Jerawata dalah masalah kulit yang ditandai dengan munculnya bintik-bintik pada beberapa bagian tubuh, seperti wajah, leher, punggung, dan dada. Bintik-bintik tersebut dapat berkisar mulai dari yang ringan, seperti komedo hitam 
dan komedo putih, hingga bintik-bintik parah yang berisi nanah dan kista.

\section{f. Penyakit kulit rosacea}

Rosacea adalah salah satu jenis penyakit kulit yang umumnya menyerang orang berkulit putih (bule). Ciri - cirinya adalah berupa bercakbercak merah, bintik-bintik kecil kemerahan dengan jumlah yang banyak pada wajah, seperti di kening dan pipi.

\section{g. Penyakit kulit seboroik}

Penyakit kulit jarang didengar. Penyakit kulit ini umumnya menyerang kulit dengan ciri-ciri berupa bercak merah, ruam-ruam agak kasar di bagian kulit kepala, wajah hingga alat reproduksi.

\section{h. Penyakit kulit eczema}

Penyakit ini sering menyerang bayi dan anak kecil dibawah lima tahun. Bisa juga disebabkan oleh faktor keturunan. Gejala eczema umumnya berupa bercak-bercak merah yang menimbulkan rasa gatal pada kulit bagian leher, siku tangan, lutut, kaki, badan. Penyakit kulit eczema bisa juga dipicu oleh pemakaian bahan-bahan kosmetik, sabun, deterjen, parfum, atau aksesori yang tak cocok dengan sensitivitas kulit. Bahkan untuk kasus yang parah, eczema dapat dipicu oleh stres dan perubahan suhu sekitar yang tak mampu diadaptasi oleh kulit.

\section{i. Kanker kulit}

Ciri khas berwarna merah gelap kemerahan dengan bercak yang tak dapat hilang. Umumnya dipicu sinar matahari, radiasi, bekas luka bakar, pengendapan darah menahun, transplansi organ, hingga faktor genetika.

\section{j. Penyakit kulit psoriasis}

Penyakit ini tidak menular, tetapi cukup sering menyerang kulit setiap orang. Ciri-ciri psoriasis adalah munculnya bercak berwarna merah, kering dan cukup tebal.

Data Penyakit Kulit yang di dapat dari sumber yang terpercaya yang menjabarkan bahwa penyakit kulit di wajah diantaranya ialah :
1. Acne Vulgaris

2. Dermatitis Perioral

3. Dermatitis Seboroik

4. Rosesea

5. Erupsi Acneiformis

\subsection{MySQL}

Merupakan sebuah implementasi dari sistem manajemen basisdata relasional (RDBMS) yang didistribusikan secara gratis.Setiap pengguna dapat secara bebas menggunakan MySQL, namun dengan batasan perangkat lunak tersebut tidak boleh dijadikan produk turunan yang bersifat komersial.MySQL sebenarnya merupakan turunan salah satu konsep utama dalam basisdata yang telah ada sebelumnya; SQL (Structured Query Language).SQL adalah sebuah konsep pengoperasian basisdata, terutama untuk pemilihan atau seleksi dan pemasukan data, yang memungkinkan pengoperasian data dikerjakan dengan mudah secara otomatis.

\subsubsection{PHP}

Hypertext Preprocessor atau di singkat PHP adalah suatu bahasa pemerograman yang digunakan untuk membuat web dinamis, walau bisa juga digunakan untuk membuat program lain. Tentunya bahasa pemerograman PHP berbeda dengan HTML, pada PHP Script/kode yang di buat tidak dapat di tampilkan pada halaman/muka website begitu saja, tapi harus diproses terlebih dahulu oleh web server lalu di tampilkan dalam bentuk halaman website di web browser, Script PHP juga dapat di sisipkan pada HTML dan script PHP selalu diawali dengan <? php dan di akhiri dengan ?> Manajamen database yang biasanya digunakan untuk pemerograman PHP misalnya seperti MySQL, tapi ada juga yang menggunakan Oracle, Microsoft Access, dan lain-lain. PHP disebut juga sebagai bahasa pemerograman script server side, karena PHP di proses pada komputer server.

\section{HASIL DAN PEMBAHASAN}

\subsection{HASIL}

1. Data Penyakit Kulit Wajah 
Berikut adalah data penyakit kulit wajah yang telah dikelompokan sesuai dengan data yang telah dikumpulkan :

Tabel 1. Data Penyakit Kulit Wajah

\begin{tabular}{|l|l|l|}
\hline No & Kode Penyakit & Penyakit \\
\hline 1 & P001 & Jerawat (Acne Vulgaris) \\
\hline 2 & P002 & $\begin{array}{l}\text { Beruntus sekitar mulut } \\
\text { (Dermatitis Perioral) }\end{array}$ \\
\hline 3. & P003 & $\begin{array}{l}\text { Beruntus sekitar kulit } \\
\text { berminyak (Dermatitis } \\
\text { Seboroik) }\end{array}$ \\
\hline 4. & P004 & $\begin{array}{l}\text { Jerawat tidak berkomedo } \\
\text { (Rosasea) }\end{array}$ \\
\hline 5. & P005 & $\begin{array}{l}\text { Efek samping obat (Erupsi } \\
\text { Acneiformis) }\end{array}$ \\
\hline
\end{tabular}

\section{Data Gejala Penyakit Kulit Wajah}

Berikut adalah data Gejala penyakit Kulit Wajah yang telah dikelompokan sesuai dengan data yang telah dikumpulkan :

Tabel 2. Data Gejala Penyakit Kulit Wajah

\begin{tabular}{|l|l|}
\hline Simbol & Gejala \\
\hline 01 & Terasa Gatal \\
\hline 02 & Muncul Komedo \\
\hline 03 & Muncul Papul/Puspul \\
\hline 04 & Beruntus \\
\hline 05 & Produksi Minyak berlebih \\
\hline 06 & $\begin{array}{l}\text { Beruntus merah yang kronis di } \\
\text { area mulut }\end{array}$ \\
\hline 07 & $\begin{array}{l}\text { Bercak merah bersisik di area } \\
\text { berminyak }\end{array}$ \\
\hline 08 & $\begin{array}{l}\text { Kelopak mata akan bengkak atau } \\
\text { berwarna kemerahan }\end{array}$ \\
\hline 09 & $\begin{array}{l}\text { Kemerahan pada batang hidung } \\
\text { dan kedua pipi yang menetap }\end{array}$ \\
\hline 10 & $\begin{array}{l}\text { Pembuluh darah dibawah kulit } \\
\text { yang terlihat jelas }\end{array}$ \\
\hline 11 & Kulit kasar dan kering \\
\hline 12 & Tidak terasa gatal \\
\hline
\end{tabular}

\section{Pengelompokan Basis Aturan}

Rule 1:

IF Muncul Komedo

AND Beruntus

AND Terasa Gatal

AND Produksi minyak berlebih

THEN Acne Vulgaria
Rule 2:

IF Muncul Papul/Pustul

AND Beruntus merah yang kronis di area mulut AND Terasa Gatal

THEN Dermatitis Perioral

\section{Rule 3:}

IF Bercak merah bersisik di area yang berminyak

AND Terasa Gatal

AND Kelopak mata akan bengkak atau berwarna kemerahan

THEN Dermatitis Seboroik

\section{Rule 4:}

IF Kemerahan pada batang hidung dan kedua pipi yang menetap

AND Pembuluh darah dibawah kulit yang terlihat jelas

AND Terasa Gatal

AND kulit kasar dan kering

THEN Rosesea

Rule 5:

IF Muncul papul/pustul

AND Muncul Komedo

AND Tidak terasa gatal

THEN Erupsi Acneiformis

\section{Interpretasi Nilai Bobot}

Tabel 3. Nilai Bobot

\begin{tabular}{|l|l|}
\hline Istilah & Bobot \\
\hline Kurang Berpengaruh & $0,1 \mathrm{~s} / \mathrm{d} 0,4$ \\
\hline Berpengaruh & $0,5 \mathrm{~s} / \mathrm{d} 0,7$ \\
\hline Sangat Berpengaruh & $0,8 \mathrm{~s} / \mathrm{d} 1$ \\
\hline
\end{tabular}

Tabel 4. Nilai Bobot Data Gejala dan Penyakit

\begin{tabular}{|l|l|l|l|l|}
\hline $\begin{array}{l}\text { Kode } \\
\text { Penyakit }\end{array}$ & Penyakit & Gejala & Interpretasi & Bobot \\
\hline P001 & $\begin{array}{l}\text { Acne } \\
\text { Vulgaris }\end{array}$ & $\begin{array}{l}\text { Muncul } \\
\text { Komedo } \\
(02)\end{array}$ & Berpengaruh & 0,7 \\
\cline { 3 - 5 } & $\begin{array}{l}\text { Beruntus } \\
(04)\end{array}$ & $\begin{array}{l}\text { Sangat } \\
\text { Berpengaruh }\end{array}$ & 0,9 \\
\cline { 4 - 5 } & $\begin{array}{l}\text { Terasa } \\
\text { Gatal } \\
(01)\end{array}$ & Berpengauh & 0,7 \\
\cline { 3 - 5 } & $\begin{array}{l}\text { Produksi } \\
\text { Minyak } \\
\text { Berlebih } \\
(05)\end{array}$ & $\begin{array}{l}\text { Kurang } \\
\text { Berpengaruh }\end{array}$ & 0,3 \\
\hline
\end{tabular}




\begin{tabular}{|c|c|c|c|c|}
\hline \multirow[t]{3}{*}{ P002 } & \multirow[t]{3}{*}{$\begin{array}{l}\text { Dermatitis } \\
\text { Perioral }\end{array}$} & $\begin{array}{l}\text { Muncul } \\
\text { papul/pu } \\
\text { stul (03) }\end{array}$ & Berpengaruh & 0,5 \\
\hline & & $\begin{array}{l}\text { Beruntus } \\
\text { merah } \\
\text { yang } \\
\text { kronis di } \\
\text { area } \\
\text { mulut } \\
\text { (06) }\end{array}$ & $\begin{array}{l}\text { Sangat } \\
\text { Berpengaruh }\end{array}$ & 0,9 \\
\hline & & $\begin{array}{l}\text { Terasa } \\
\text { Gatal } \\
(01)\end{array}$ & Berpengaruh & 0,7 \\
\hline
\end{tabular}

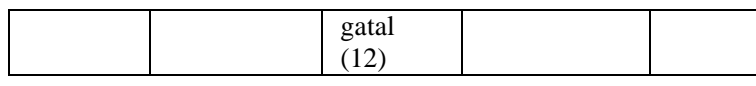

Perhitungan Certainty Factor:

1. Penyakit Acne Vulgaris :

$$
\begin{aligned}
\mathrm{P} 001= & \mathrm{MB}(\mathrm{A}, 04)+(\mathrm{MB}(\mathrm{A}, 04) * \\
& (1-\mathrm{MB}(\mathrm{A}, 04))) \\
= & 0.90+(0,90 *(1-0.90))=0,99
\end{aligned}
$$

2. Penyakit Dermatitis Perioral :

$\mathrm{P} 002=\mathrm{MB}(\mathrm{B}, 06)+(\mathrm{MB}(\mathrm{B}, 06) *$

\begin{tabular}{|c|c|c|c|c|}
\hline \multirow[t]{3}{*}{ P003 } & \multirow[t]{3}{*}{$\begin{array}{l}\text { Dermatitis } \\
\text { Seboroik }\end{array}$} & $\begin{array}{l}\text { Bercak } \\
\text { merah } \\
\text { bersisik } \\
\text { di area } \\
\text { yang } \\
\text { berminy } \\
\text { ak (07) }\end{array}$ & $\begin{array}{l}\text { Sangat } \\
\text { Berpengaruh }\end{array}$ & 0,8 \\
\hline & & $\begin{array}{l}\text { Terasa } \\
\text { Gatal } \\
(01)\end{array}$ & Berpengaruh & 0,6 \\
\hline & & $\begin{array}{l}\text { Kelopak } \\
\text { mata } \\
\text { akan } \\
\text { bengkak } \\
\text { atau } \\
\text { berwarn } \\
\text { a } \\
\text { kemerah } \\
\text { an }(08) \\
\end{array}$ & $\begin{array}{l}\text { Kurang } \\
\text { Berpengaruh }\end{array}$ & 0,4 \\
\hline \multirow[t]{4}{*}{ P004 } & \multirow[t]{4}{*}{ Rosacea } & $\begin{array}{l}\text { Kemerah } \\
\text { an pada } \\
\text { batang } \\
\text { hidung } \\
\text { dan } \\
\text { kedua } \\
\text { pipi } \\
\text { yang } \\
\text { menetap } \\
(09) \\
\end{array}$ & $\begin{array}{l}\text { Sangat } \\
\text { Berpengaruh }\end{array}$ & 0,9 \\
\hline & & $\begin{array}{l}\text { Pembulu } \\
\text { h darah } \\
\text { dibawah } \\
\text { kulit } \\
\text { yang } \\
\text { terlihat } \\
\text { jelas } \\
(10) \\
\end{array}$ & $\begin{array}{l}\text { Sangat } \\
\text { Berpengaruh }\end{array}$ & 0,8 \\
\hline & & $\begin{array}{l}\text { Terasa } \\
\text { Gatal } \\
(01) \\
\end{array}$ & Berpengaruh & 0,7 \\
\hline & & $\begin{array}{l}\text { Kulit } \\
\text { Kasar } \\
\text { dan } \\
\text { Kering } \\
\text { (11) }\end{array}$ & $\begin{array}{l}\text { Kurang } \\
\text { Berpengaruh }\end{array}$ & 0,4 \\
\hline \multirow[t]{3}{*}{ P005 } & \multirow[t]{3}{*}{$\begin{array}{l}\text { Erupsi } \\
\text { Acneiformis }\end{array}$} & $\begin{array}{l}\text { Muncul } \\
\text { papul/pu } \\
\text { stul (03) }\end{array}$ & $\begin{array}{l}\text { Sangat } \\
\text { Berpengaruh }\end{array}$ & 0,8 \\
\hline & & $\begin{array}{l}\text { Muncul } \\
\text { komedo } \\
(02)\end{array}$ & $\begin{array}{l}\text { Kurang } \\
\text { Berpengaruh }\end{array}$ & 0,3 \\
\hline & & $\begin{array}{l}\text { Tidak } \\
\text { terasa }\end{array}$ & Berpengaruh & 0,5 \\
\hline
\end{tabular}

$(1-\mathrm{MB}(\mathrm{B}, 06)))$

$=0.90+(0,90 *(1-0.90))=0,99$
3. Penyakit Dermatitis Seboroik:

$\mathrm{P} 003=\mathrm{MB}(\mathrm{C}, 07)+(\mathrm{MB}(\mathrm{A}, 07) *$

$(1-\mathrm{MB}(\mathrm{A}, 07)))$

$=0.80+(0,80 *(1-0.80))=0,96$

4. Penyakit Rosacea :

$$
\begin{aligned}
\mathrm{P} 004= & \mathrm{MB}(\mathrm{D}, 09)+(\mathrm{MB}(\mathrm{D}, 10)+(\mathrm{MB}(\mathrm{D}, 01 \\
& *(1-\mathrm{MB}(\mathrm{D}, 09)-\mathrm{MB}(\mathrm{D}, 10))) \\
= & 0.9+0.8+(0.7 *(1-0.9-0.8))=1.21
\end{aligned}
$$

5. Penyakit Erupsi Acneiformis :

$$
\begin{aligned}
\mathrm{P} 001= & \operatorname{MB}(\mathrm{E}, 03)+(\mathrm{MB}(\mathrm{E}, 03) * \\
& (1-\mathrm{MB}(\mathrm{A}, 03))) \\
= & 0.80+(0,80 *(1-0.80))=0,96
\end{aligned}
$$

\section{Usecase}

Model Use Case menjelaskan mengenai aktoraktor yang terlibat dengan perangkat lunak yang dibangun beserta proses-proses yang ada di dalamnya. Berikut adalah usecase diagram diagnosa penyakit kulit wajah.

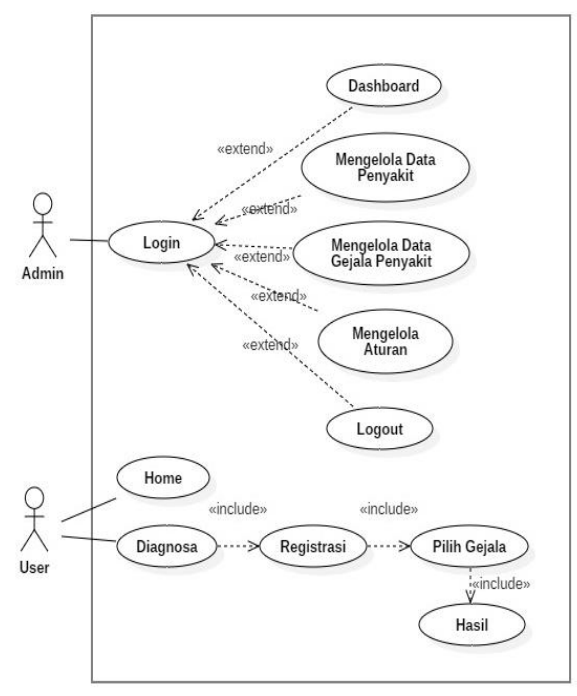


Gambar 2 Usecase Sistem Pakar Diagnosa Penyakit Kulit Wajah

\section{Class Diagram}

Class diagram yang digunakan untuk menampilkan beberapa kelas yang ada dalam beberapa sistem perangkat lunak yang akan dikembangkan. Classdiagram menunjukan hubungan antara class dalam sistem yang sedang dibangun dan bagaiman mereka saling berkolaborasi untuk mencapai tujuan. Berikut ini digambarkan class diagram dari Sistem

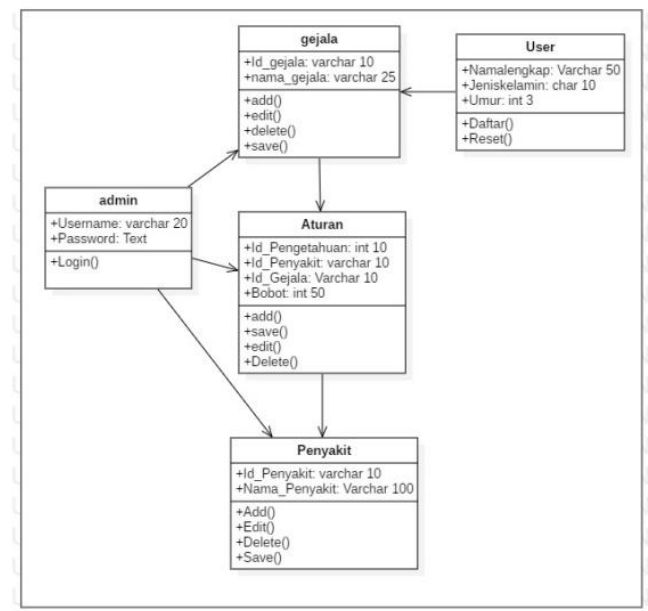

Gambar 3.Class Diagram

\subsection{PEMBAHASAN}

\subsubsection{Halaman Utama}

Tampilan halaman utama adalah tampilan pertama kali saat pasien dan admin mengakses situs web, adapun tampilannya adalah sebagai berikut :

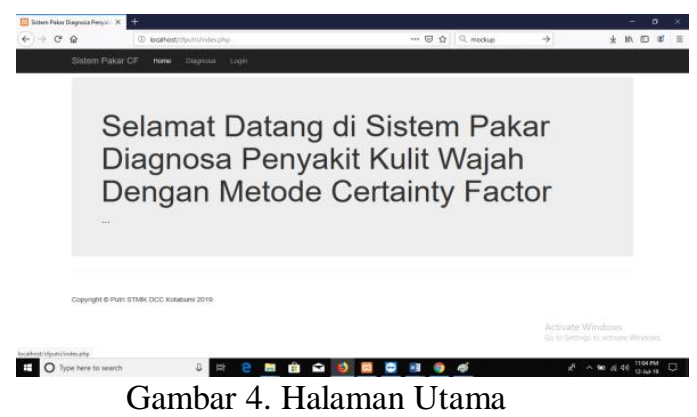

\subsubsection{Halaman Registrasi User}

Halaman Registrasi User merupakan halaman pertama user sebelum melakukan proses diagnosa, user akan menginput Nama Lengkap, Jenis Kelamin, Umur. Adapun tampilannya adalah sebagai berikut:
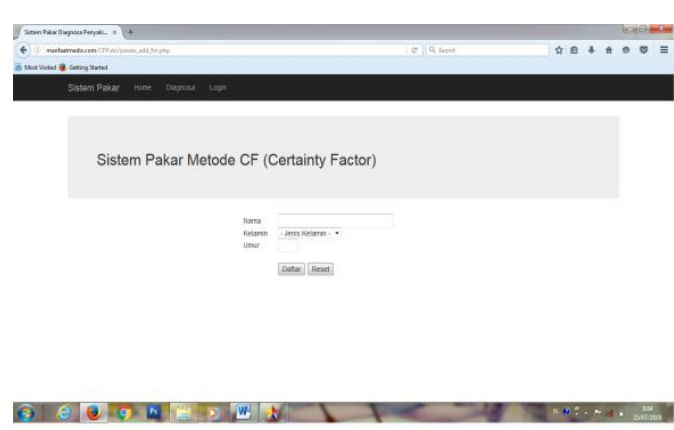

Gambar 5. Halaman Registrasi User

\subsubsection{Halaman Diagnosa}

Halaman diagnosa merupakan halaman yang berisi gejala gejala yang di derita pasien. Pasien akan mengisi beberapa gejala yang dialami untuk mengetahui penyakit yang dideritanya, adapun tampilannya adalah sebagai berikut :

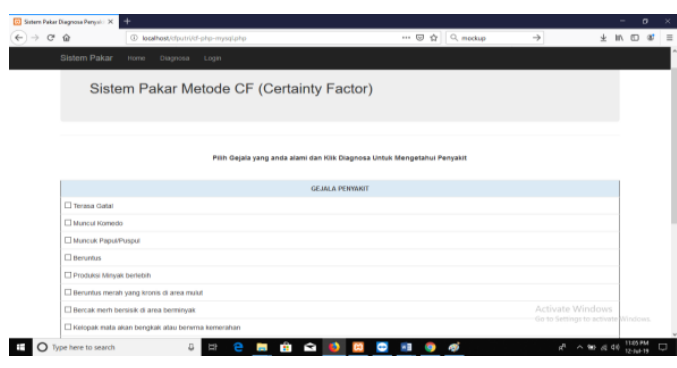

Gambar 6. Halaman diagnosa

\subsubsection{Halaman Hasil Konsultasi}

Halaman hasil konsultasi adalah halaman yang beisikan tentang penyakit yang diderita pasien berdasarkan gejala yang dipilih, adapun tampilannya sebagai berikut :

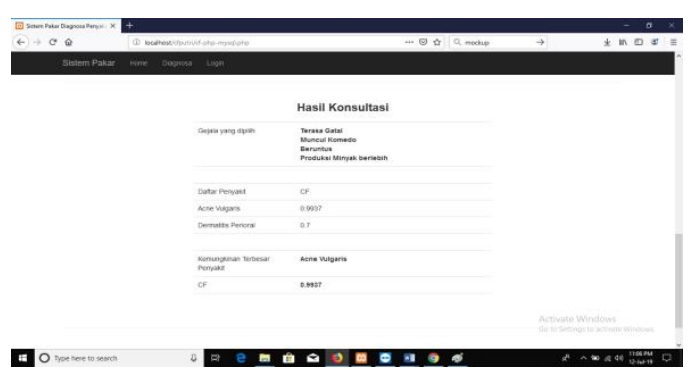

Gambar 7. Halaman Hasil Konsultasi 


\subsubsection{Halaman Login Admin}

Halaman login admin berfungsi untuk memberikan hak akses kepada admin dalam melakukan penambahan, pengeditan dan menghapus data pasien, adapun tampilannya adalah sebagai berikut :

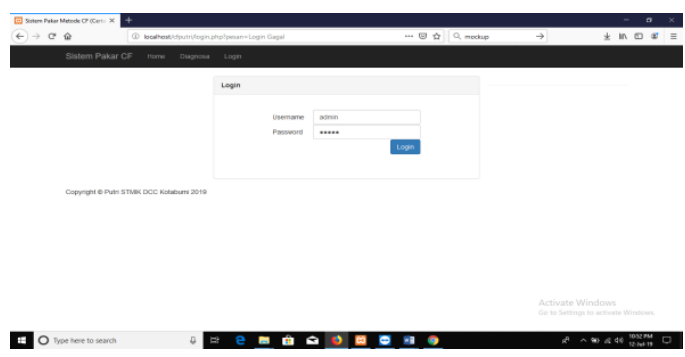

Gambar 8. Halaman Login Admin

\subsubsection{Halaman Utama Admin}

Halaman utama admin adalah halaman awal setelah login, berisi beberapa pilihan menumenu yang disediakan aplikasi, adapun tampilannya sebagai berikut :

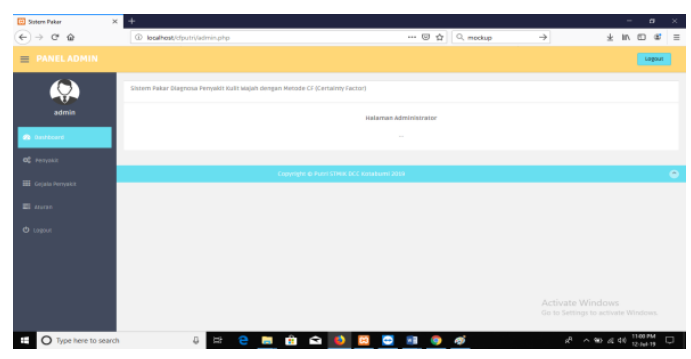

Gambar 9. Halaman utama admin

Tabel 5. Testing Black Box

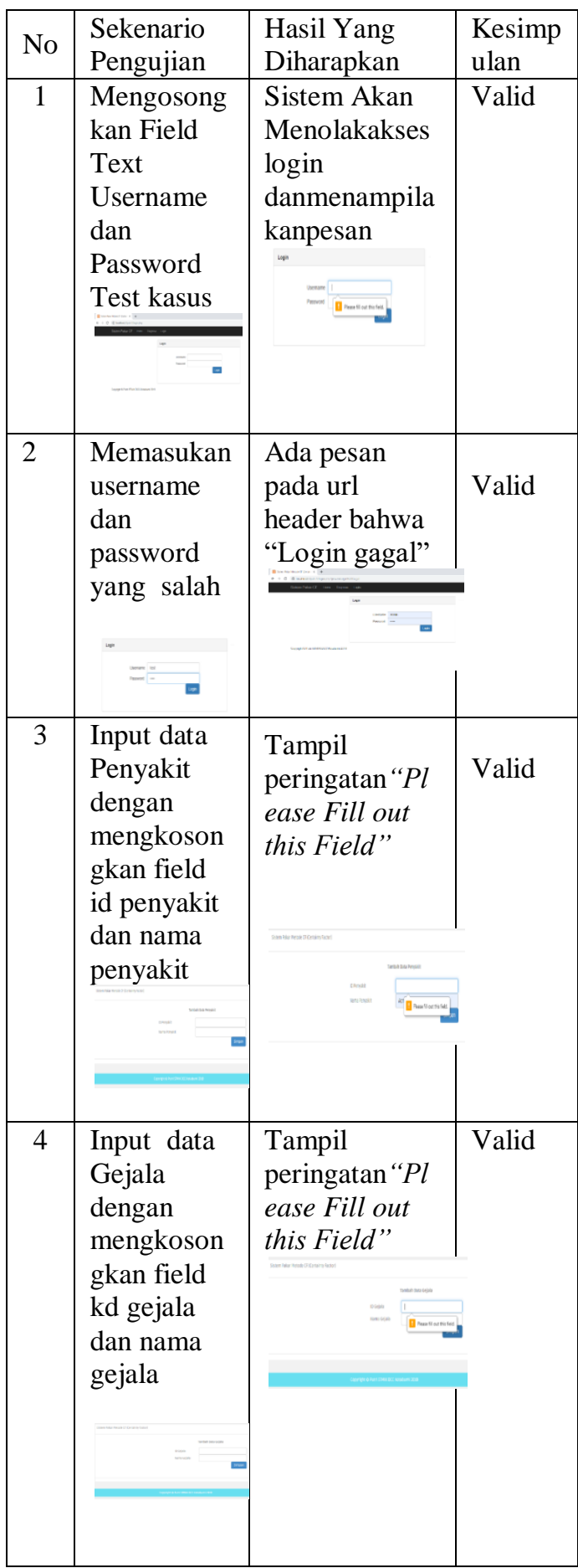




\begin{tabular}{|l|l|l|l|}
\hline 5 & $\begin{array}{l}\text { Input data } \\
\text { Gejala } \\
\text { dengan } \\
\text { mengkosong } \\
\text { kan field kd } \\
\text { gejala dan } \\
\text { nama gejala }\end{array}$ & $\begin{array}{l}\text { Tampil } \\
\text { peringatan "Pl } \\
\text { ease Fill out } \\
\text { thisField" }\end{array}$ & Valid \\
& & & \\
& & & \\
& & \\
& & \\
\end{tabular}

\section{KESIMPULAN}

Dari hasil penelitian yang dilakukan penulis, maka penulis dapat mengambil beberapa kesimpulan antara lain sebagai berikut :

1. Dengan adanya aplikasi sistem pakar ini dapat membantu pakar dalam memberikan informasi dalam mendiagnosa awal jenis penyakit kulit wajah pada user menggunakan aplikasi sistem pakar ini.

2. Aplikasi sistem pakar ini, dapat mendiagnosapenyakit kulit wajah yang di alami pasien berdasarkan gejala-gejala yang telah dimasukkan.

3. Aplikasi sistem pakar ini menggunakan metodecertainty factor serta menggunakan bahasa pemrograman PHP dan database MySQL yang dikomposisikan sedemikian rupa sehingga memudahkan dalam menggunakan sistem pakar yang akan dibuat.

\section{DAFTAR PUSTAKA}

[1] Supriyatna, A. Metode Extreme Programming Pada Pembangunan Web Aplikasi Seleksi Peserta Pelatihan Kerja. Jurnal Teknik Informatika, 11(1). 2018

[2] Sukamto, \& Shalahuddin. Analisa dan Desain Sistem Informasi. Yogyakarta: Andi Offset. 2013
[3] Rika Rosnelly. Sistem Pakar Konsep Dan Teori. Andi. Universitas Potensi Utama. 2012

[4] Riandari, Fristi Sistem Pakar Mendiagnosa Penyakit Kulit Wajah Menggunakan Metode Certainty Factor. STMIK Pelita Nusantara. 2017

[5] Sri Yasita, Yohana Dewi Lulu, \& Rika

Perdana Sari. Sistem Pakar Penyakit Kulit Pada Manusia Menggunakan Metode Certainty Factor Berbasis Web. Seminar nasional teknologi informasi, komunikasi dan industri (SNTIKI). 4, 2-3. 2012

[5] Ketut Arlin Aryani, Dewa Gede Hendra Divayana, \& I Made Agus Wirawan. Sistem Pakar Diagnosis Penyakit Jerawat Di Wajah Dengan Metode Certainty Factor. Universitas Pendidikan Ganesha Singaraja. 2017

[6] Khairina Eka Setyaputri, Abdul Fadlil, dan Sunardi. Analisis Metode Certainty Factor pada Sistem Pakar Diagnosa Penyakit THT. Universitas Ahmad Dahlan. 2018

[7] Rismawati. Sistem Pakar Untuk

Mendiagnosa Penyakit Kulit Pada Wajah. Universitas Islam Negeri Alauddin Makassar. 2018

[8] Ardhy, Ferly. "Implementasi Sistem Pakar Untuk Mendiagnosa Penyakit Tulang Pada Manusia Menggunakan Metode Forward Chaining." Jurnal Informasi Dan Komputer 7.1 (2019): 29-34. 